\title{
A POESIA COMO FONTE HISTÓRICA PARA O ESTUDO DA FILOSOFIA DO DIREITO
}

\author{
POETRY AS HISTORICAL SOURCE TO THE STUDY OF \\ PHILOSOPHY OF LAW
}

Moacyr Motta da Silva"

\begin{abstract}
Resumo: $\mathrm{O}$ estudo procura demonstrar, a partir da leitura da clássica poesia de Homero, que os versos produzidos pelo autor constituem uma rica fonte de temas para a Filosofia do Direito. Releva assinalar que a obra pesquisada se constitui de uma poesia. Homero parece tê-la escrita com o objetivo de demonstrar que, até mesmo na arte poética o artista pode valer-se dos princípios da Moral, da Ética, da Justiça para assinalar que nenhuma Sociedade se sustenta na riqueza da conquista por assaltos, traições, mentiras. A partir deste universo temático, o autor elaborou os seguintes tópicos: A predição da Tragédia; 2.0 A Guerra entre Dois Reinados: causa primeira; 3.0 Leitura I Da Moral. Leitura II Da Política; Leitura III Estética poética; Leitura IV O simbólico - a Balança como Instrumento de Equilíbrio; Leitura V Do Juiz. Leitura VI Da Cultura Religiosa e Sociedade; Leitura VII A poesia de Homero como Instrumento pedagógico. A pesquisa reflexiva desenvolvida na poesia de Homero, procura destacar temas voltados para à Filosofia do Direito.
\end{abstract}

Palavras-chave: Filosofia do direito. Moral. Política. Sociedade.

Abstract: This study aims to demonstrate, from reading the classic poetry of Homero, that its verses, created by the author, form a rich source of topics to Philosophy of Law. So, it is important to detach that the work which was object of this research is a poetry. Homero seems to have it written with the aim of demonstrating that, even in its poetic art, the artist uses the principles of Moral, Ethics, Justice to point that no Society sustains itself in the richness of achieving robbery, treachery, lies. From this universe of themes, the author elaborated the following topics: The Prediction of Tragedy; 2.0 The war between two kingdoms: the first cause; 3.0 First Reading of Moral; Second Reading of Politics; Reading III Poetic Esthetics, Reading IV Symbolic - the balance as an Instrument of Equilibrium; Reading V The Judge; Reading VI About Religious and Society; Reading VII The Poetry of Homero as an educational instrument. This introspective research, developed based on the poetry of Homero, aims to detach topics related to Philosophy of Law.

Key-words: Philosophy of law. Morality. Politics. Society.

Doutor e Mestre em Direito pela Universidade Federal de Santa Catarina. Professor aposentado da Universidade Federal de Santa Catarina, Curso de Direito: Programas de Mestrado e Doutorado. Professor titular do Curso de Pós-Graduação Stricto Sensu em Ciência Jurídica da Universidade do Vale do Itajaí. Membro da Academia Catarinense de Filosofia de Santa Catarina. Email: amello@univali.br 


\section{INTRODUÇÃO}

$\mathrm{O}$ artigo que ora apresenta-se, tem o seu olhar voltado para a poesia ${ }^{1}$ de Homero $^{2}$, obra que consagrou as letras da cultura da Grécia da Antiguidade 3. Por entender que a poesia de Homero permite várias leituras, ou seja, além da clássica Guerra de Tróia, ${ }^{4}$ de cunho épico, ${ }^{5}$ os versos descortinam um universo temático de diferentes assuntos. Como resultado da pesquisa, foi possível criarse o seguinte conjunto de temas: a) a predição da Tragédia. b) a Guerra entre Dois Reinados: causa primeira. c) da Moral. Leitura. d) Da Política. e) Estética poética. f) O simbólico - a Balança como Instrumento de Equilíbrio. g) Do Juiz. Leitura. h) Da Cultura Religiosa e Sociedade. Leitura. I) a poesia de Homero como Instrumento pedagógico. Por se tratar de obra de natureza poética, o autor teve a necessidade de socorrer-se da leitura de pensadores contemporâneos de Homero, tais como Hesíodo, Platão. O autor contou, igualmente, com auxílio teórico de pesquisadores da atualidade como Comte Spoville, Emille Durkheim, Jonathan Barnes e outros referidos em notas de roda-pé.

${ }^{1}$ A Ilíada se constitui de poema criado exclusivamente pela imaginação de Homero. Neste particular, a Ilíada, não representa uma releitura da história dos Aqueus e dos Tróianos. Não se trata de episódios históricos vividos entre as duas culturas. Há, porém certos momentos do poema, nos quais o poeta refere-se a cidades, costumes, religião, decisões de justiça extraídos do contexto de sua época (Atenas, Ftía, Cálidon, Tróia) Século VIII aC.). Do mesmo modo, a Ilíada escapa à categoria de mito. Pesquisas desenvolvidas nesse sentido, indicam que a Ilíada foi integralmente escrita. Provavelmente, grafada.

${ }^{2}$ A cronologia de Homero não é precisa. Ela pode ser considerada, com tempo provável anterior ao século VIII aC. Isto porque, há registros de que sua obra Ilíada foi escrita nos meados daquele período. Duas cidades gregas reivindicam a terra natal de Homero, Esmirna e Quios. Homero não se destacou apenas como poeta clássico da Grécia da Antiguidade. Sua obra literária permanece viva até hoje.

${ }^{3}$ Seus principais poemas foram a Ilíada e a Odisséia. O estilo literário de Homero é o épico. A Ilíada de Homero constitui um dos ricos acervos literários da cultura da Grécia da Antiguidade. O poema se constitui de vinte quatro cantos. O conflito entre os Aqueus (gregos) e Tróianos durou, aproximadamente, dez anos. Homero faz um recorte nos episódios, para alcançar um espaço de tempo de aproximadamente, cincoenta e cinco dias.

${ }^{4} \mathrm{O}$ nome dado à obra Ilíada provém da palavra Ílio ou Ilion, com o significado de Tróia (de Iliun deriva do Latim Ilium). Tróia representa o nome dado à uma cidade lendária. $\mathrm{O}$ sítio arqueológico que se presume ter sido a cidade Estado de Tróia pertence, na atualidade, à Turquia. A histórica cidade-Estado de Tróia, que à época serviu de inspiração para Homero criar o genial poema Ilíada, integrava à Grécia. $\mathrm{Na}$ atualidade, pesquisas arqueológicas revelam a existência de restos de um sítio arqueológico que se supõe ter sido a tradicional Tróia descrita por Homero.

${ }^{5}$ A palavra épica designa, para o presente estudo, atos relativos a acontecimentos heroicos. Também versos que descrevem uma epopeia, feitos heroicos. Épico é empregado na literatura, na poesia. 
O objetivo a ser alcançado neste estudo consiste em demonstrar que a poesia de Homero constitui uma das fontes históricas para a Filosofia do Direito.

$\mathrm{O}$ autor considera importante desenvolver-se pesquisas em áreas de saberes localizadas em outros sítios do conhecimento, posto que há sempre a esperança de encontrar-se assuntos que ampliem o pensar crítico, reflexivo do estudioso do Direito. A partir deste propósito, o autor foi estimulado a penetrar no interior dos versos de Homero, com o objetivo de identificar dados históricos, políticos que contribuíssem para se explicar, por exemplo, como era entendido o significado de justiça, de moral, de direito, de costumes ligados à religião. A pesquisa foi exitosa, estimuladora para novos empreendimentos, por conseguir alcançar o objetivo do trabalho.

\section{A PREDIÇÃO DA TRAGÉDIA}

Na leitura da Ilíada, Homero põe na boca de Helena, a seguinte sentença: "Sobre nós fez Zeus abater um destino doloroso, para que no futuro sejamos tema de canto para homens, ainda por nascer" (HOMERO, 2005, Canto VI, verso 355). As palavras de Helena parecem antecipar a previsão de um futuro carregado de infelicidades. Homero comunica ao leitor, que por obra de Zeus, a vida de Helena e Alexandre servirá de inspiração para os poetas que ainda virão. A leitura do verso parece indicar que Zeus, na condição de Deus supremo de todos os deuses e homens, possuía o poder de influir no destino de cada pessoa humana. Essa prerrogativa, ao que se infere da leitura do poema, leva a supor-se que Homero acreditava na existência de um Deus supremo. Em outro trecho do poema, Menelau, primeiro esposo de Helena pede a sanção máxima para os dois infieis: "que morram aqueles dois, para quem já foi preparada a morte e o destino" (HOMERO, 2005, Canto III, verso 100). Provavelmente, o poema traz a mensagem, no sentido moral, de dizer que todo aquele que infringir princípios, regras consagradas pela Sociedade, se submeterá às sanções por ela impostas. Esse vaticínio parece uma das sanções morais do poema. Aceitando-se este entendimento, reconhece-se que a Ilíada assume um caráter moral. Observado o poema por este ângulo, deduz-se que Homero foi educador moral.

\section{A GUERRA ENTRE DOIS REINADOS: CAUSA PRIMEIRA}

O poema apresenta seu epicentro numa relação de amor considerada imoral (HOMERO, 2005, Canto III). Os protagonistas centrais do poema são a bela mulher Helena, esposa de Menelau, rei da Lacedemónia e o jovem Alexandre, um dos filhos de Príamo, rei de Tróia. Alexandre era considerado por seus compatriotas, como pessoa devassa, bajulador, um verdadeiro ser imoral. Sua principal preocupação centrava-se na aparência física. Foi durante uma viagem diplomática que Alexandre fez à Lacedemónia, que o mesmo conheceu a bela 
Helena. O jogo de amor entre o jovem Alexandre e a sedutora Helena nasceu entre paredes do palácio do esposo Menelau. O ápice das relações diplomáticas alcança seu ponto de tensão, quando a jovem e bela Helena, esposa de Menelau o trai com Alexandre, em um dos aposentos do palácio do esposo.

$\mathrm{Na}$ fúria da paixão desenfreada, Helena é raptada por Alexandre para viver a espúria relação de amor, na cidade de Tróia. O impensado ato de intensa emoção amorosa que tomou conta de Alexandre e Helena foi como o dique de um rio, que, ao romper-se provoca devastação às regiões ribeirinhas. Em desagravo ao rapto de Helena, poucos foram os dias para que se iniciasse a sangrenta guerra entre Aqueus e Troianos.

O episódio de irrefletida paixão não teria maiores consequências, não fora a condição política que atingiu a honra do rei Menelau.

$\mathrm{O}$ esposo da bela Helena pertencia à nobre magistratura política Esparta. $\mathrm{O}$ jovem Alexandre cometera duas grandes traições. A primeira contra o rei Menelau que o hospedou em sua jurisdição política. A segunda, contra a magistratura de seu próprio pai Priamo, rei de Tróia.

Inconformados com o rapto de Helena, os Aqueus decidem atacar Tróia para recuperar a bela esposa de Menelau. Dois exércitos posicionam-se frente a frente, para degladiarem entre si. A falange dos Troinanos, coloca-se em posição de defesa. A falange dos Aqueus, fortemente armada, prepara-se para o mortal ataque visando recuperar a honra de sua cidade.

Vítimas e ofensores acham-se diante dos portões centrais de Tróia. Menelau toma a dianteira de seu grupo e propõe ao príncipe Alexandre um duelo entre ambos. A cena é marcada por insultos entre os contendores. Heitor, um dos irmãos de Alexandre sugere que a guerra seja decidida entre Menelau e Alexandre.

Menelau aceita a proposta. Observa que o pacto seja selado pelo sangue de um dos adversários. Helena, do alto do palácio de Alexandre teme a iminência da terrível luta. O duelo dá vantagem a Menelau, diante de sua condição física e habilidades para guerras. Porém, a deusa Afrodite vem em socorro de Alexandre, e o leva envolto em uma névoa, para Helena.

O prodígio da deusa Afrodite retira Alexandre, definitivamente, da luta. Foi reconhecida a vitória de Menelau sobre Alexandre. Diante da frustrada vingança, tem início a guerra entre Aqueus e Troianos. Os Aqueus por suas habilidades para a guerra conquistam o adversário (HOMERO, 2005, Canto III).

A guerra entre os contendores adquire proporções inimagináveis. Porém duas delas se destacam como epílogo. A primeira corresponde à proposta de Pátroclo, o leal amigo de Aquiles. O jovem Pátroclo pede a Aquiles para 
comandar a batalha, pois era seu desejo recuperar a honra dos Aquianos. O amigo empresta-lhe o faiscante elmo, as armas e a armadura. Aquiles adverte ao jovem guerreiro que apenas afaste os Troianos, da cercania das naus, sem os perseguir. Pátroclo, porém desobedece Aquiles e se aproxima das cercanias da cidade de Tróia. Esse é o instante em que Heitor, o matador de homens, luta com Pátrocolo e o mata, cruelmente. Inconformado com a brusca interrupção do destino do amigo, Aquiles jura vingar-se. Enfurecido, combate entre Aquiles e Heitor, um dos irmãos de Alexandre (HOMERO, 2005, Canto XXIV).

\section{LEITURA}

\subsection{Da Moral}

O poeta Homero, provavelmente pretendeu evidenciar, como tema de fundo do poema a Ilíada, o sentido moral. Entre as virtudes morais, certamente, a fidelidade representa uma das principais ações positivas nas relações humanas. ${ }^{6}$ A fidelidade não convive com a mentira, a traição, pois ambas constituem vícios morais. A fidelidade de natureza conjugal exige de cada um dos matrimoniais, permanente zelo no sentido do bem, do bom nas relações entre si e com a Sociedade. A fidelidade dos esposos requer voluntariedade e necessita, sempre, da memória do outro. A fidelidade expressa-se pela ação voluntária e representa um dos verdadeiros fundamentos dos costumes morais.

$\mathrm{O}$ ato de infidelidade conjugal praticado por Helena, ao entregar-se a Alexandre constituiu uma ofensa, uma quebra da ordem moral consagrada tanto por Aqueus, quanto pelos Troianos (HOMERO, 2005, Canto III). A vil traição não teria maior repercussão, não fosse a elevada condição política de Helena, esposa do rei da Macedenónia e de Alexandre ter sido recepcionado em palácio do rei Menelau, em missão diplomática de sua cidade (Tróia).

Outro momento a destacar na Ilíada, corresponde às virtudes morais demonstradas por dois adversários políticos. Priamo soberano rei dos Troianos desce de sua magistratura que o mesmo devolva o cadáver de seu filho Heitor. Priamo já com avançada idade, tivera conhecimento de que Aquiles matara seu filho Heitor, por vingança da morte de Pátroclo. A súplica de Priamo era para não deixar os restos mortais de seu filho insepulto. Sua intenção era levar o cadáver de Heitor, para enterrá-lo em sua terra natal (Tróia). Ponderava o ancião Priamo, que mesmo em situações de guerra, era costume dos povos cobrir com terra os mortos e, humildemente, roga a Aquiles, príncipe da

${ }^{6}$ Pensamentos inspirados na leitura da obra: COMTE-SPOVILLE. Pequeno Tratado das Grandes Virtudes. Trad. Eduardo Brandão. São Paulo: Martins Fontes, 2004. 391p. 
Tessália, o matador de Heitor, para combate. Já havia mais de dez dias que os restos mortais de Heitor eram arrastados pelo chão poeirento. No céu, abutres em voos macabros, preparavam-se para festejar o próximo banquete (o cadáver de Heitor). Diante dos insistentes pedidos de perdão de Priamo, já de cabelos brancos e alquebrados pelo tempo, Aquiles, o adversário político, aquele compadece-se e autoriza a entrega do dilacerado corpo de Heitor. O gesto de humildade de Priamo, apoiado no legítimo pedido, provoca sentimento do perdão em Aquiles. Certamente, Homero pretendeu dar um sentido de elevação moral à guerra entre os dois povos (Aqueus e Troianos). Embora Homero tenha enfatizado com riqueza de detalhes a crueldade das mortes entre (Aqueus e Troianos), há um momento em que as paixões, as sangrentas lutas dão lugar à trégua. A tensão da guerra é irmã do anseio da paz. Homero, certamente quis mostrar que além da extrema cólera, do desenfreado desejo de vingança, o ser humano ainda é capaz de perdoar o adversário. Os versos escritos na Ilíada têm um sentido do humano. Homero revela que o Homem, por mais rude que seja, traz no recôndito de sua essência, sentimentos de amor e ódio, afago e desprezo, tensão e tranquilidade, injustiça e perdão. Ações dessa natureza revelam que a pessoa humana, caminha em dois pólos distintos. É necessário desenvolver-se o equilíbrio entre a razão e a sensibilidade. $\mathrm{O}$ meio termo entre os pontos opostos conduz o Ser humano à excelência moral.

\subsection{Da Política}

A seguinte leitura da Ilíada revela determinados momentos que se pode situá-los na esfera da política pública. ${ }^{7}$ Tem-se que considerar que Homero não era jurista ou filósofo, senão um poeta. Os versos de Homero dão conta da existência de um Conselho do povo, no qual as decisões que envolviam o destino da cidade passavam por uma Assembleia ou Conselho do povo (HOMERO, 2005, Canto III). O poeta canta em versos, o significativo momento de tensão pré-guerra, onde se discutia entre os Aqueus, o modo pelo qual a cidade de Tróia seria invadida. $\mathrm{O}$ autor assinala que toda decisão política, para ganhar a simpatia e concordância de Zeus necessita submeter-se à aprovação de uma Assembleia.

Com o mesmo estilo com que o poeta descreve as lutas entre Aqueus e Troianos, Aquiles esmera-se na movimentação dos membros do Conselho

\footnotetext{
${ }^{7}$ Por opção metodológica, o presente estudo deixa de entrar no mérito de aspectos destacados de ordem política que ocorreram na antiga civilização grega. Entre eles citam-se: o regime político das cidades antigas da Grécia, que nem sempre foram de um só modelo político.
} 
do povo (HOMERO, 2005, Canto II). Em certo momento dos diálogos parlamentares, uma voz se levanta para dizer que a todos é assegurado falar. Porém, não é bom todos mandarem. Apenas um que possui o cetro tem "o direito de legislar, para que decida por todos" (HOMERO, 2005, Canto II). Os debates de ideias, as fundamentações dos parlamentares, em sessões plenárias constituíam eficazes instrumentos de educação política. Os versos, neste particular, não revelam confrontos de ofensa ética entre os parlamentares. Neste particular, Homero demonstra a existência de certo grau de educação política nas Assembleias do povo. Do mesmo modo, os versos da Ilíada demonstram que a organização política dos Aqueus, não se constituía de uma horda de homens, sem princípios e objetivos. A declaração de guerra ou de paz não se dava por simples impulsos impensados, estimulados por sentimentos de vingança e de ódio. O povo, em Assembleia apresentava moções de interesse geral. O rei na prerrogativa de soberano magistrado político do povo possuía poder de legislar. Aquilo que o Conselho do Povo votava, era encaminhado ao Magistrado. Somente após transformada em lei a vontade do Conselho, a proclamação adquiria legitimidade. A importância dos versos deste tópico encontra-se na versão histórica em que Homero recupera o modo de vida política de um povo. Do ângulo da História Política das Sociedades, a Ilíada se constitui em notável fonte de referência política. Quiçá, uma das reservas históricas para o estudo da Democracia da antiguidade.

\subsection{Da Estética poética}

A próxima leitura do poema de Homero corresponde ao âmbito da estética poética. Para o presente estudo, estética poética corresponde à ideia de harmonia, de proporção e de adequação entre início, meio e fim no sentido literário. Em síntese, os versos construídos na Ilíada buscam o belo. A riqueza das palavras aparece na harmonia dos sons, na combinação das cores das vestes, na descrição do cheiro da poeirenta terra, no desenho das armaduras, no resfolgar dos cavalos. Tudo escrito com esmero de detalhes como se fosse uma tela de um artista plástico. O poeta expressa sua sensibilidade artística, no emprego das palavras, na demonstração de acontecimentos das batalhas, bem assim, a demonstração de sentimentos humanos. Uma das técnicas literárias utilizadas por Homero consiste no emprego de metáforas. ${ }^{8}$ A estética poética aparece, também,

${ }^{8}$ Forma gramatical empregada na língua portuguesa para designar um objeto ou qualidade mediante a aplicação de outra palavra para significar outro objeto ou qualidade, com certa semelhança. Exemplos: "grito de guerra" Canto I, verso 490; 
no domínio do poeta na adequação das palavras, tanto sobre a revelação de expressões fisionômicas de seus personagens, bem como a narração de diálogos travados entre penetração da lanças no corpo do adversário, todo o cenário assume certo sentido de aparente realidade. Chama a atenção do pesquisador, a capacidade de Homero de colocar o leitor dentro da cena histórica, nela descrevendo ventos, tempestades e causticante sol, tal como a realidade fosse. Com igual domínio, Homero (2005) insere o leitor no ambiente do diálogo, levando-o a imaginar-se estar ao vivo entre os falantes. A seguir reproduz-se versos escolhidos no poema, nos quais aparecem as figuras poéticas: "o vento inchou o centro da vela de ondas de púrpura" (Canto I verso 480); “à Aurora de róseos dedos" (Canto VI verso 175). "Quanto a Pátroclo, enquanto Aqueus e Troianos combatiam de roda da muralha, afastados das naus velozes, ficou sentado na tenda do amavioso Eurípilo, deleitando-se com palavras, enquanto sobre a ferida dolorosa aplicava fármacos que apaziguassem as negras dores" (Canto XV); "uma nuvem negra de dor de apoderou de Aquiles" (Canto XVIII); "Ai de mim, desgraçada. Infeliz parturiente de um Príncipe. Eu que dei à luz um filho irrepreensível forte, excelso entre os herói, cresceu rápido como uma viga” (Canto XVIII); "E os cocheiros amedrontaram-se quando viram o fogo incansável, terrível, por cima da cabeça do magnânimo filho de Peleu" (Canto XVIII); "Toda planície se enchera de homens e de cavalos e refulgia o bronze. $A$ terra ressoava debaixo dos pés, ao embaterem uns contra os outros” (Canto XX). "Eneias...será que os troianos de demarcaram um domínio senhorial superior aos dos outros : terra de pomares e lavoura para nela habitares no caso de me matares?" (Canto XX); "Não é possível lutar contra Zéus Crónida. Ao nível dele nem o poderoso Aqueloo se coloca, nem a grande força do Oceano de profundas correntes, de quem todos os rios procedem e todo o mar, todas as fontes e todas nascentes profundas" (Canto XXI) (lamento da esposa de Heitor) "Ela estava sentada ao tear no íntimo do recesso do alto do aposento, a tecer uma trama purpúrea de dobra dupla e nela bordava flores de várias cores." (Canto XXII) (no epílogo do poema, a súplica do ancião Priamo: "Pensa no teu pai, ó Aquiles semelhante aos deuses. Ele que tem a minha idade, na soleira da dolorosa velhice" (Canto XXIV).

“coração de leão" Capítulo V, verso 635; " pastor do povo “ Canto VII, verso 465; " aroma da planície " Canto VIII, verso 545; " corrente cruel "Canto X, verso 455; " chicote reluzente " Canto X, verso 500; " aurora divina " Canto XI, verso 720; " mansão de Hades" Canto XIV, verso 455; "fogo incansável” Canto XVIII, verso 225; “ úivos de alegria" CantoXVIII, verso 570; “ passar a perna aos mais nobres "Canto XXII 605 "ondas dolorosas "Canto XXIV, verso 5. 
A Filosofia do Direito, enquanto área de saber que tem por objeto investigações teóricas sobre os princípios universais do Direito, o exame crítico, reflexivo dos valores de justiça, da ética, da moral, do humano como centro de atenção, tem na Filosofia da Linguagem, seu principal apoio. Do ângulo da estética poética, os versos da Ilíada constituem importante tema para ser estudado sob a ótica da Filosofia da Linguagem. Em sentido comparativo pode-se dizer que a Filosofia do Direito e a Filosofia da Linguagem, se interagem como um sistema na linha do conhecimento. As duas disciplinas, embora distintas quanto a seus objetos, são harmônicas entre si. A Ilíada de Homero não só constitui rico acervo da arte estética, como também representa instrumento para a arte de transmitir ideias, com precisão designativa. $O$ poema de Homero necessita ser lido, interpretado e assimilado pelo pesquisador da Filosofia do Direito.

\subsection{O Simbólico - a Balança como Instrumento de Equilíbrio}

Outro momento enriquecedor encontrado nos versos da Ilíada consiste na simbologia da balança. $O$ poema relata a sangrenta luta entre Aqueus e Troianos. A baixa dos mortos registrava-se de ambos os lados. $\mathrm{O}$ sangue dos contendores derramava no solo, diante do arremesso das impiedosas lanças do bronze. Por todos os lados via-se o precioso líquido da vida de Aqueus e dos Troianos. Ainda que numericamente mais forte fosse a falange dos Troianos, os Aqueus não abandonavam a poeirenta zona de combate. Foi a partir desse cruel cenário que Homero poetiza: "Mas nem assim conseguiam pôr os Aqueus em debandada, porquanto eles se mantinham firmes, como a fiandeira honesta que segura a balança e levanta os pesos e a lã de cada lado, para igualizar, de modo a ganhar uma ninharia para os filhos, assim de forma equável se esticou a luta e a batalha, até que Zeus outorgou a gloria a Heitor" (HOMERO, 2005, Canto XII Versos 430, 435). A criatividade poética de Homero destaca-se na comparação em que o autor faz do equilíbrio de forças entre Aqueus e os Troianos em relação a habilidade da fiandeira. Essa ergue a balança para pesar dois volumes de lã, colocados em cada um dos pratos. O trato da lã parece ser sua fonte de economia. A grandeza poética de Homero está em buscar nas coisas simples da vida, exemplos de trabalho captados do cotidiano da cultura grega.

O objetivo da fiandeira consistia em igualizar o peso da lã de um prato em relação ao do outro. O exemplo estampado nestes versos parece ter sido extraído dos costumes da época. Tal como o filósofo Aristóteles virá, séculos mais tarde, a adotar em seus textos, exemplos do cotidiano para desenvolver suas ideias, Homero o faz com a figura da fiandeira. A balança dotada de dois pratos móveis, suspensos por uma lâmina em posição vertical e colocados 
horizontalmente cada um nas extremidades, constituía instrumento destinado a pesar e igualizar pesos de diferentes valores. Trata-se de costume de um povo que passa a ser reproduzido em versos por Homero. Esse útil instrumento, todavia, tem sua origem em tempos imemoriais. Não há provas que tenha nascido no Mundo da Antiguidade Ocidental ou Oriental.

O emprego da balança nos versos da Ilíada assume um caráter simbólico. Por isto, merece certas considerações. A batalha dos Aqueus para vencer os Troianos funda-se num dado relevante. Corresponde ao sentimento moral dos Aqueus, que precisavam da vitória, a qualquer preço. Mesmo que a força física dos Aqueus estivesse aquém do necessário para derrotar os Troianos, o sentimento de justiça constituiu a força moral que os estimulava à luta. Sabiam os guerreiros Aqueus que se a batalha fosse perdida, a punição seria dobrada. A conquista de Helena pelos Troianos, seguida da derrota em campo de batalha.

A representação da fiandeira de lã e o emprego da balança, nos versos da Ilíada remete o leitor à simbologia da justiça, nos seguintes fundamentos:

Constitui prática do mundo contemporâneo, a representação da instituição da Justiça, em forma de uma figura simbólica chamada Diké e ou Thémis. ${ }^{9}$ A primeira representa a justiça humana (Dikê). A segunda aparece como símbolo da justiça dos deuses (Thémis) (BRANDÃO, 2007, v. 1, p. 134, 161, 163, 169, 201; CHAUI, 2002, v. 1, p. 498; GUTHRIE, 1995, p. 67; HESÍODO, 2007, p. 79; JAEGER, 2003, p. 134-5). Sua função era a de aconselhar Zeus sobre a norma (divina) mais justa a ser aplicada. Tanto uma como a outra figura simbólica ostentam na mão direita, uma balança, em cujos pratos busca o equilíbrio. $\mathrm{Na}$ mão esquerda seguram uma espada, representativa da força do direito. ${ }^{10}$

Parece provável pensar-se que o poeta Homero ao citar o exemplo da fiandeira com a balança, (igualizar os pesos de lã), tenha se inspirado no símbolo da deusa Diké. Neste particular estudo, registra-se que séculos mais tarde, aparecem os Filósofos Pré-Socráticos, os Sofistas, e bem assim os clássicos gregos Sócrates, Platão e Aristóteles. Em princípio, não foram encontrados registros que os pensadores assinalados simbolizaram a justiça, mediante representação de Diké ou de Thémis. É certo, porém, que alguns deles leram a Hilíada. ${ }^{11}$ Ainda que

${ }^{9}$ No sistema jurídico Romano-Germânico constitui prática comum a simbolização da justiça, mediante a figura simbólica da Diké ou Themis (órgãos do Poder Judiciário, em todos os níveis de jurisdição).

${ }^{10}$ Estudos realizados em torno dos dois símbolos culturais apontam ora (Diké), ora. (Thémis). Por isto, a existência de controvérsias sobre a representatividade das mesmas

${ }^{11}$ Entre os filósofos pesquisados foram encontrados os seguintes: Pré-Socráticos Xenófanes (BARNES, 1997, p. 111); Heráclito (BARNES, 1997, p. 122); Ipon de Crotona (BARNES, 1997, p. 264); Demócrito (BARNES, 1997, p. 308; GUTHRIE, 1996, v. 6; PLATÃO, 1996, par. 363 a; 364 d; 377 d; 378 d e citações em outros parágrafos da mesma obra). 
permaneça incógnita a origem do autor que consagrou a figura simbólica da Justiça, é certo que as civilizações que sucederam Homero, até os dias de hoje, consagram a representação de uma mulher, que sustenta na mão direita, uma balança, e na esquerda, uma espada figurativa do Direito. Diante da força dos costumes, neste particular, o símbolo da justiça seja como Diké ou de Thémis assume valor de consciência coletiva, provavelmente de âmbito universal.

Revela-se importante a figura simbólica da fiandeira de Homero. Talvez o poeta pretendeu dizer em versos, que a fiandeira, com o emprego da balança quis buscar o equilíbrio entre dois pesos. Porém, nem sempre a balança suporta nos dois pratos, valores da mesma natureza. Em um deles tem o peso da força física dos contendores, em outro, o do valor moral de um povo.

Trazendo-se o tema para a Filosofia do Direito, pode-se pensar na possibilidade de se revisitar as Teorias do Direito, com o objetivo de situar a Justiça, nos moldes da fiandeira. Equivale pensar uma proposta de estudos da Teoria da Justiça para a Pós-Modernidade, dentro da qual se busquem fundamentos de equilíbrio entre o valor jurídico em relação aos valores éticos, morais e espirituais. Esta proposta de enfoque visa romper com a dogmática visão do direito positivo.

\subsection{Do Juiz}

A riqueza temática da Ilíada não se limita às lutas entre Aqueus e Troianos, nem mesmo ao profundo amor entre a bela Helena e o jovem Alexandre. Homero, na sua capacidade criativa, poetiza, em versos, uma cena de casamento, em cujo cenário aparece a figura do Juiz. Numa pequena cidade da Grécia, mancebos e mulheres dançavam ao som de flautas e liras. Era uma linda festa de bodas, na qual as noivas, saídas de suas casas, entoavam canto nupcial. O ambiente era iluminado por tochas lampejantes. O regozijo nupcial era compartilhado por outras mulheres que se colocavam em pé. Porém, um conflito surgiu próximo aos festejos. Dois homens discutiam entre si o pagamento de indenização, devido a um assassinato, supostamente atribuído a um deles. Um dos homens alegava que nada devia, posto que tudo fora pago em declarações. O outro declarava que não aceitava qualquer decisão. Dois talentos de ouro era o valor entregue àquele que proferisse a sentença mais justa. Os anciões (Juízes) encontravam-se sentados em pedras polidas dentro de um círculo, considerado sagrado (HOMERO, 2005, Canto XVIII, versos 490, 495, 500, 505). Homero não anuncia o desfecho da contenda judicial. Parece deixar ao leitor, a imaginação quanto à atuação do Juiz frente ao destino dos dois homens. A leitura do Canto revela importantes dados. O primeiro corresponde à da existência de um Juiz da Comunidade, 
dotado de poderes para julgar questões dessa natureza. Daí subtender-se que a Comunidade dos homens não aceitava a justiça privada. Ou seja, à época já havia o consenso da Sociedade em conferir a uma pessoa do povo, a atribuição para julgar. (eram escolhidos anciões por sua experiência de vida) $\mathrm{O}$ segundo dado a assinalar liga-se ao aspecto formal. Um local próprio era escolhido para a realização da audiência pública. Os Juizes sentavam-se sobre pedras polidas, especialmente talhadas para acomodar os juízes. Um círculo considerado sagrado constituía o local em que os Juízes desempenhavam suas funções. $\mathrm{O}$ processo de julgamento era, integralmente, oral. O chão sagrado em forma de ć́rculo decorria do respeito, do reconhecimento que a Comunidade devotava ao local de representação da Justiça. Os Juízes tinham diante de si dois talentos de ouro, previamente depositados, para remunerar aquele que proferisse a sentença mais justa. Os versos não revelam os fundamentos da sentença que consistiria a decisão mais justa. A questão leva a pensar-se em inúmeras respostas. Um raciocínio parece razoável. Somente outra Corte de Juízes seria competente para examinar o justo ou injusto, para o caso sob julgamento. Releva-se a considerar que certas impropriedades jurídicas observadas nos versos se justificam, uma vez que Homero não era jurista, senão poeta. A leitura da Ilíada, nesta perspectiva, denota que a instituição do julgamento de pessoas que transgrediam as leis da Sociedade é de tempos imemoriais.

\subsection{Cultura Religiosa e Sociedade}

Não há como estudar religião sem se conhecer aspectos sócio-econômicospolíticos do povo que a cultua. Essa regra não escapa, nem mesmo à Sociedade Grega da Antiguidade. Tal sucede na quase maioria das vezes, os registros, as notícias que revelam temas históricos, políticos de um passado distante, têm origem em fontes que se referem a dados sócio-econômicos e políticos. A leitura da Ilíada, nesta perspectiva, constitui um rico material de fontes dessas naturezas (HOMERO, 2005, p. 503). Além da obra de Homero, o autor apoiase em outro poeta, seu contemporâneo. Trata-se da pessoa de Hesíodo, uma das personalidades da arte poética que viveu ao tempo de Homero. ${ }^{12}$

Do ponto de vista econômico, a llíada relata que os gregos já dominavam a cultura do vinho, como, também, a produção do ouro, da prata e de pedras preciosas. Mediante a técnica da fundição de metais sólidos, os gregos

${ }^{12}$ Hesíodo nasceu e viveu em Ascra, por volta do século VIII aC. Duas são as obras poéticas que consagram Hesíodo: Os Trabalhos e os Dias (HESÍODO, 2007, p. 101) e A Origem dos Deuses (HESÍODO, 2007, p. 159). 
elaboravam armaduras, espadas, carruagens, bem como instrumentos de guerra. Figuras mitológicas talhadas em alto relevo aparecem nos brilhantes elmos, nas taças e nas armaduras. Os versos da Ilíada também referem à produção de tecidos (em teares). Do mesmo modo, o desenvolvimento da química na criação de tinturas (tecidos e couros) Uma das explicações para todo esse avanço, parece estar na cultura milenar de seu povo. Estes dados captados dos versos da Ilíada proporcionam certa dimensão das condições sócio-econômicas e políticas do povo grego da Antiguidade. A cultura religiosa parece não destoar do grau de desenvolvimento da então Sociedade grega.

Uma das iniciais observações que aparece na Ilíada consiste na pluralidade de deuses. A esse dado chama-se de cultura religiosa politeísta. ${ }^{13}$ No poema de Homero, a religião mostra-se de caráter politeísta. Zeus é considerado pai dos homens e dos deuses (HOMERO, 2005, Canto XV, verso 10). Entre outras divindades que gravitam no universo do poema, destacam-se: Febo Apolo, de cabelos de luz e dileto de Zeus; Afrodite, a deusa dotada da capacidade de ocultar as pessoas, em situações desesperadoras; Hera, de alvos braços; Thémis, de lindo rosto; Tetis, a deusa dos pés prateados; Íris a mensageira de Zeus. Ainda que a poesia de Homero considere Zeus como deus no ápice das divindades, há que se admitir que nenhuma religião mostra-se homogênea, uníssona (VERNANT, 2006, p 10). Em princípio, cada pessoa era livre para louvar seus deuses, sobretudo Zeus. O sentido de religião mesclava-se com a política, a Sociedade civil, a justiça. Essa era a cultura religiosa desenvolvida pelos gregos da antiguidade.

Conforme se extrai dos versos de Hesíodo, a instituição da Justiça, de certo modo tinha correspondência com a religião (HESÍODO, 2007a, p. 35). Hesíodo refere sobre a existência de reis venerandos, que sob a proteção de Zeus, emitem sentenças dotadas de reta justiça (HESÍODO, 2007, versos, 80, 85, $90,95)$. Os venerandos reis eram pessoas da própria Sociedade. Suas sentenças não eram escritas, senão orais. Os fundamentos dessas sentenças guardavam harmonia com as tradições da vida pública e social. Consideradas como fórmulas normativas não escritas eram conhecidas por $(d i ́ k a i)^{14}$. As fórmulas (díkar) eram consagradas pelos membros da Sociedade. Importante assinalar

${ }^{13}$ Politeísmo. A palavra Deus no idioma grego tem o nome Theos. Já a palavra Polis do grego designa muitos, vários. Portanto, Politeísmo significa a crença em inúmeros deuses.

${ }^{14}$ A palavra Dike, no idioma grego é representada por justiça. No idioma Latino aparece com (dico), (dicere), com o sentido de dizer. 
que os reis necessitavam de boa memória para julgar as questões que lhes eram submetidas, em conformidade com o caso anterior (Provavelmente, o critério do Precedente que, mais tarde veio a ser no direito anglo saxônico.)

A crença, a consagração aos Deuses, a veneração de ambientes de ordem religiosa aparecem com destaque na Ilíada. No poema, a cultura religiosa revelase no diálogo entre o Homem e entidades divinas, como se fossem presentes em sua vida cotidiana.

Duas figuras da mitologia religiosa aparecem nos versos da Ilíada, a primeira, o Olimpo constituía o habitat natural do deus Zeus, senhor de todos os deuses e dos homens. Segundo a mitologia grega antiga, o Olímpo pertencia a uma cadeia de montanhas, junto às altas nuvens. Do cume do Olimpo, Zeus observava as ações dos humanos; a segunda, Hades representava, na antiga religião da Grécia, o lugar de profanações, em cujas profundezas da terra habitavam os mortos condenados por suas vidas errôneas. $\mathrm{Na}$ voz dos deuses aparece, com freqüência, a advertência da morada do Hades. $O$ humano que descumprisse as orientações de Zeus ou de seus deuses menores teria o destino do Hades.

Homero põe nos seus personagens longas orações de religiosidade "Ouve-me Senhor do arco de prata, deus tutelar de crise e da sacratíssima Cila, que pela força reges Ténedo ó Esminteu. Se alguma vez ao belo templo te pus um tecto, ou queimei para ti as gordas coxas de touros ou de cabras, faz que se cumpra isto que te peço: que paguem com tuas setas os Dânaos as minhas lágrimas" (HOMERO, 2005, Canto I, verso 40).

A prece é respondida por Aquiles: "Toma coragem e profere o oráculo que souberes. Por Apolo dilecto de Zeus a quem tu rezas, ó Calcas, e por intermédio de quem aos Dânaos dás oráculos, enquanto eu for vivo e contemplar a luz da terra ninguém te porá a mão pesada junto às côncavas naus, ninguém de todos os Dânaos, nem que tu refiras a Agamêmnon, que agora entre todos os Aqueus declara ser o mais nobre” (HOMERO, 2005, Canto I, verso 85).

Nos versos a seguir, observa-se outra prece dedicada ao deus Zeus.

"Zeus pai, que reges o Ida, gloriosíssimo, máximo. Concede-me que chegue estimado e miserando à tenda de Aquiles e envia uma ave, célere mensageiro, a ave que de todas te é mais cara e pela força é a maior de todas: que apareça do meu lado direito, para que eu próprio veja com os olhos e possa ir confiante até as naus dos Dânaos de rápidos poldros” (HOMERO, 2005, Canto XXIV verso 310$)$.

As invocações aos deuses aparecem, em regra, como apelos a uma força maior, sem a qual o Homem não teria condições de realizar seus anseios.

Homero deixa claro que tanto Zeus quanto os demais entes divinos são 
voltados para a justiça e a paz. Constitui princípio religioso não atender pedidos de ato de vingança, de injustiça. Na força dos entes divinos da família de Zeus, não há proteção pelo mal, senão para o bem. Os versos descritos nos cantos buscam a humildade, a solidariedade, o perdão.

A ira, a cólera, a vingança perpassa todos os cantos nas palavras dos mortais Aqueus e Troianos. Vícios morais não são aceitos como princípios de agir dos deuses. Por esse motivo, as orações a Zeus e aos demais deuses tanto são feitas pelos reis e príncipes, como também, pelo povo em geral.

A leitura do poema parece indicar que tanto Zeus quanto os demais deuses eram invocados pelos humanos, para alcançar um fim material (a conquista de uma batalha, a proteção contra a falsidade, igualmente para evitar a morte sangrenta). Somente no último canto da Ilíada, mediante a interferência de Zeus, o idoso Priamo consegue com o gesto de humildade, o perdão de Aquiles.

Observa-se na leitura da Ilíada não haver uma espécie de catálogo de codificação de preceitos religiosos. De igual modo, não existia um local público, especialmente destinado às orações. O Olimpo considerado a casa de Zeus figurava puramente no imaginário social. A consciência religiosa do povo grego da antiguidade nascia e se desenvolvia pela via oral. Cada família ou grupo social orava, prestava culto a seus deuses no âmbito de suas unidades familiares. Daí, provavelmente, a diversidade de interpretações dos preceitos religiosos.

\subsection{A Poesia de Homero como Instrumento de Educação}

A arte poética de Homero reproduzida na Ilíada constitui, até os dias hoje, considerável instrumento de Educação. ${ }^{15}$ Os versos narrados na líada revelam que Homero, foi também, um educador.Provavelmente, tenha sido um de seus objetivos criar uma história que, na essência, procurasse ensinar ao povo da Grécia caminhos que conduziam a princípios morais, éticos e políticos. A concepção que se extrai do trabalho artístico de Homero, no alvorecer deste Terceiro Milênio, parece coincidir com o pensamento de Platão. A leitura da obra República de Platão dá noticias de que o filósofo já conhecera e apreciara a poesia de Homero. Platão considerou Homero, como verdadeiro educador da Grécia. ${ }^{16}$ Aceitando-se a ideia de que Platão era um extremado crítico dos

${ }^{15}$ A noção de Educação que orienta este tópico inspira-se na leitura da obra de Melo (2000, p. 104).

${ }^{16}$ Por conseguinte, ó Glaucon quando encontrares encomiastas de Homero, a dizerem que esse poeta foi o educador da Grécia, e que é digno de se tomar por modelo no que toda a administração e a educação humana, para aprender com ele a regular toda 
Sofistas, parece que o filósofo teve a necessidade de rever seu ponto de vista, diante da poesia de Homero. Observe-se que Platão pede que todo aquele que tecer palavras de louvor, de honras a Homero, seja beijado, como sendo das melhores pessoas. $\mathrm{O}$ reconhecimento de Platão por considerar Homero o verdadeiro educador da Grécia Antiga, representa uma consagração de natureza universal. Justo porque Platão representa um dos filósofos clássicos da Grécia Antiga, cujos ensinamentos conseguem ultrapassar os milênios.

Não somente Platão reconheceu Homero como educador dos gregos. Estimase que todo aquele que assimilar os conteúdos morais, éticos, da Ilíada, há de ver na pessoa de Homero, um educador. O poeta revelou-se um verdadeiro pedagogo na arte de ensinar. Parece que, de forma direta, Homero procurou mostrar que a escolha entre o caminho do bem, do justo, em oposição ao mal, à injustiça, leva à elevação dos costumes morais. Homero demonstrou que a humildade não é privativa de pessoas desprovidas de riquezas ou pertencentes a camadas sociais de pouca ou nenhuma influência na Sociedade. A humildade, segundo se extrai do pensamento de Homero constitui virtude moral inerente à condição humana. A humildade se opõe à soberba. A humildade denota amor, respeito ao outro. A palavra humildade revela sabedoria, ou seja, a capacidade do Ser de se considerar como os demais, sem exaltação à sua posição política, hierárquica e ou outro fator que o eleve no meio social.

A falta de cuidado nos limites da humildade pode incorrer na depreciação de si, do Ser. A virtude da humildade recomenda ação prática, de forma a tornar-se um hábito, a ser imitado.

Passagens dos versos da Ilíada dão conta que o pai de Heitor, magistrado dos Troianos e de avançada idade, suplica humildemente, a Aquiles, que o autorize a não deixar insepulto seu filho. É de se observar que os versos da Ilíada não apenas focalizam a moral como ideia, mas, sobretudo, como ação.

A Ilíada revela que a vida da rainha e esposa Helena sustentada pela riqueza, pela criadagem, pela luxúria de suas vestes e palácios não foi suficiente para afastá-la do adúltero convívio com o belo Alexandre, o insidioso representante do reino de Tróia.

nossa vida, deves beijá-los e saudá-los como sendo as melhores pessoas que é possível, e concordar com eles em que Homero é o maior de todos os poetas e o primeiro dos tragediógramos, mas reconhecer que, quanto a poesia, somente se devem receber na cidade hinos aos deuses e encômios aos varões honestos e nada mais (PLATÃO, 1996, p. 606 et seq.). Nota. A palavra encomiasta no idioma português significa quem faz discurso de louvor. Quem faz elogio à alguém o a alguma coisa. Já a palavra encômio designa discurso, canto ou louvor a alguém. 
Essa visão Homero retrata com o esmero de sua criatividade poética. Os sentimentos de vergonha, de pudor, que sentiam os Aqueus, diante da traição, da infidelidade de sua rainha, não poderiam servir de motivo para ações impensadas. A razão deveria orientar a condução do pensamento do povo ultrajado (Aqueus). Homero destaca que a educação política deveria ser observada, até mesmo, nos modos de invadir os muros de Tróia. Somente após a tomada de decisão pelos membros do Conselho do Povo, tem início a guerra. Nesse particular, deduz-se que Homero pretendeu demonstrar a necessidade de maturidade política, para o encaminhamento de escolha de ação que envolveria a vida de centenas de pessoas. A recuperação da honra ultrajada diante da traição de Helena e do Troiano Alexandre não poderia ser resgatada por atos impensados, de puro sentimento. A leitura da Ilíada, nesta perspectiva, constitui fonte de ensinamentos éticos, morais e políticos, como contribuições temáticas à Filosofia do Direito.

\section{CONSIDERAÇÕES FINAIS}

Entre as conclusões, o trabalho reforça a ideia, segundo a qual, há necessidade do pesquisador do Direito romper com a tradicional linha de leitura centrada, exclusivamente na Ciência Jurídica.

Mediante esta opção, abre-se um leque de estudos, por exemplo, na Antropologia, na Ética, na Fenomenologia, na História, na Moral, na Política, na Psicologia, na Economia, na Sociologia.

Para tanto, precisa-se ousar, estimular o senso de criatividade. A experiência prática demonstra que até mesmo na poesia há dados nos quais o poeta revela a cultura, o modo de pensar e de agir da Sociedade que o cerca.

Homero, ao discorrer em seus versos as lutas sangrentas entre Troianos e Aqueus, ainda que não tenha sido um historiador, descreve aspectos da forma de organização política da Sociedade da Grécia Antiga.

Em regra, o poeta cria sua arte, envolto em ambientes políticos, sociais, econômicos e religiosos de sua época. Nestes cenários, a fantasia e o real assumem a fala do poeta. Mediante a inspiração de seu espírito, seus personagens e ambientes se confundem entre o mito e o real.

Homero ao escrever a Ilíada, parece não fugir a observação. A Ilíada não constitui um tratado sobre a arte de guerrear. Homero parece evitar apologia ao emprego da guerra, considerada como o extremo instrumento empregado pelo homem, diante do esgotamento de todas as formas racionais para aplacar a ofensa, a injustiça. 
O estudo dos vinte e quatro Cantos da Ilíada de Homero descortina ao pesquisador, um universo de temas significativos para a Filosofia do Direito.

Além do viés central da poesia, (épico) a obra mostra um rico mosaico dos costumes da Grécia Antiga: a) política da boa vizinhança desenvolvida pelos reis das Cidades-Estados da Grécia, mediante viagens a nações estrangeiras com os objetivos diplomáticos e comerciais; b) instituição de Assembleias ou Conselhos do povo criado para debates e resoluções de assuntos da cidade; c) instituição de Juízes nomeados para o julgamento de pessoas acusadas de delito; d) processo exclusivamente oral, adotado pelos Juízes da comunidade; e) critério de justiça fundado nos costumes morais da Comunidade; f) cerimônias e sepultamentos de pessoas mortas; g) preservação do casamento monogâmico; h) repulsa à traição matrimonial; i) cultura da religião apoiada na crença de deuses orientados por um único Deus considerado imortal; i) liberdade familiar ou comunitária de escolher o Deus de sua vocação religiosa; j) falta ou inexistência de uma taboa ou carta de recomendações religiosas; $k$ ) a crença na figura simbólica de um lugar destinado às almas dos mortos.

A Ilíada vista por estes prismas permite deduzir que os versos nela contidos representam uma das fontes reveladoras dos hábitos, do imaginário e dos ideais da Sociedade da Grécia Antiga.

No contexto do poema, observa-se a genial imaginação de Homero na trama de diálogos de seus personagens. O poeta retrata o ambiente cultural dos costumes de uma época (Séc.VIII aC.). Ressalte-se que tanto os Aqueus quanto os Troianos tinham como hábito, o saque de animais como cavalos, bois e ovelhas, inclusive bens de uso comestíveis (colheitas de cereais).

A invasão do domínio alheio fazia parte da prática dos mais fortes contra os mais fracos.

Os versos da Ilíada narram essas ações como se fossem condutas normais, talvez justificadas pela necessidade da sobrevivência humana.

O poeta não menciona a invasão e ou a ocupação de terras cultiváveis ou de outra qualidade produtiva.

Daí deduzir-se que, neste particular, a Sociedade grega não aceitava essas práticas (imorais).

A arte poética versada no poema de Homero veio confirmar uma ideia, uma concepção do autor.

Não há âmbito do conhecimento humano que não possa contribuir para a Filosofia do Direito. Homero ao descrever sobre a índole de seus personagens, nada encobre sobre os mesmos. Ulisses era um impiedoso saqueador de cidades. Alexandre um príncipe dotado de apenas belo corpo físico, em contraste com 
seu caráter de bajulador, egoísta e conquistador de mulheres. Havia deusas fieis aos conselhos de Zeus. Havia, igualmente, aquelas que, por desobediência ao Deus supremo, induziam os humanos aos vícios. A escolha para o caminho do justo e do injusto, da virtude e do vício dependia, exclusivamente, de cada um em particular.

A atenta observação da Ilíada leva o pesquisador a entender que a religião da Grécia da Antiguidade não constituía uma instituição homogênea.

As manifestações religiosas diferiam de família para família, de um grupo social para outro. O primeiro dado a assinalar está na pluralidade de Deuses. Entre eles, um destaca-se como o supremo Deus e senhor dos demais. Trata-se de Zeus, inclusive o Deus de todos os gregos. De acordo com a crença mitológica, os deuses possuíam corpo à semelhança do ser humano.

A distinção estava nos poderes que assumiam. Puramente pelo culto ao imaginário, aceitavam que Zeus e demais deuses tinham poderes para intervir na vida dos humanos. Segundo o imaginário, os fenômenos da natureza constituíam exemplos da manifestação dos deuses: trovões, elevação dos mares, dos ventos, das colheitas.

Em outras palavras, os deuses constituíam representações de forças da natureza.

Não havia uma tábua de prescrições determinando certo tipo de comportamento no sentido do bom em relação ao mal, do injusto frente ao justo.

Releva destacar que determinadas ações dos humanos constituíam motivos de alegria aos deuses. (a bondade, a justiça, o perdão). Outras os encolerizavam, até o próprio Zeus (HOMERO, 2005, Canto I, Verso 10).

Os personagens da Ilíada dialogam com os deuses, sobretudo com Zeus. Isto revela certa aproximação e intimidade entre os mortais e os deuses.

A poesia não mostra a existência de oráculos ou dias especiais para conversar-se com as divindades. A partir do estudo da Ilíada leva-se a deduzir que a religião dos gregos da Antiguidade aceitava que Zeus e os demais deuses eram imortais. Já o homem grego, para a religião, era um ser mortal. Um dado interessante aparece na pesquisa, Homero admite que, após a morte, a alma não repousa com o corpo. ${ }^{17}$ Os versos do poeta dizem que a alma sai do corpo para a mansão de Hades. Lá permanece para a eternidade.

\footnotetext{
17 "Assim dizendo, cobriu-o o termo da morte. E a alma voou-lhe do corpo para o Hades, lamentando o seu destino, deixando para trás a virilidade e a juventude. E para ele já morto, assim disse o divino Aquiles: "Morre. O destino eu aceitarei, quando Zeus quiser que se cumpra e os outros deuses imortais” (HOMERO, 2005, Canto XXII, verso 365).
} 
Assinala-se que, séculos mais tarde, surge na Filosofia Pré-Socrática, a concepção da existência da alma como ente do corpo humano, com vida. Após a morte, a alma dissipa-se do corpo para retornar, novamente, em outro corpo (SILVA, 2008, p. 230). Por fim, o estudo da religião leva a pensar-se que, provavelmente, nesse momento histórico esteja nascendo na cultura religiosa da Grécia Antiga, o que se denomina igreja. Uma organização moral constituída de grupo de pessoas (sacerdotes e fiéis) unida pela mesma crença religiosa. (DURKHEIM, 2003).

\section{REFERÊNCIAS}

BARNES, Jonathan. Filósofos pré-socráticos. Tradução de Júlio Fischer. São Paulo: Martins Fontes, 1997.

BRANDÃO, Junito de Souza. Mitologia grega. 19. ed. Petrópolis: Vozes, 2007. v. 1.

CHAUI, Marilena. Introdução à história da filosofia. Dos pré-socráticos a Aristóteles. São Paulo: Companhia das Letras, 2002. v. 1.

COMTE-SPOVILLE. Pequeno tratado das grandes virtudes. Tradução de Eduardo Brandão. São Paulo: Martins Fontes, 2004.

DURKHEIM, Émile. As formas elementares da vida religiosa. Tradução de Paulo Neves. São Paulo: Martins Fontes, 2003.

GUTHRIE, William Keith Chambers. Historia de la Filosofia Griega. Introducción a Aristóteles. Trad. Alberto Medina Gonzáles. Madrid: Editorial Gredos. 1999. v. 6.

. Os Sofistas. Tradução de João Rezende Costa São Paulo: Paullus, 1995.

HESÍODO. A origem dos deuses. Tradução de Jaa Torrano 7. ed. São Paulo: São Paulo: Iluminuras, 2007a.

. Os trabalhos e os dias. Tradução de Mary de Camargo Neves Lafer. 7. ed. São Paulo: Iluminuras, 2007b.

HOMERO. Ilíada. Tradução de Frederico Lourenço. Lisboa: Livros Cotovia, 2005.

JAEGER, Werner. Paidéia: a formação do homem grego. Tradução de Artur M. Parreira. São Paulo: Martins Fontes, 2003.

MELO, Osvaldo Ferreira de. Dicionário de Política Jurídica. Florianópolis: OAB-SC, 2000. 
PLATÃO. A República. 8. ed. Tradução de Maria Helena da Rocha Pereira. Lisboa: Fundação Calouste Gulbenkian, 1996.

SILVA, Moacyr Motta da. Direito, justiça e virtude moral \& reflexões. 2. ed. rev. e atual. Curitiba: Juruá, 2008.

VERNANT, Jean-Pierre. Mito e religião na Grécia Antiga. Tradução de Joana Angélica DÁvila Melo. São Paulo: Martins Fontes, 2006.

Artigo recebido em 20/04/10 e aprovado para publicação em 12/10/10 
